\title{
The Effect of Knowledge, Promotion, and Religiosity on Intention to Use Islamic Banking Services
}

\author{
Kardoyo $^{1}$, Ahmad Nurkhin ${ }^{1}$, Muhsin ${ }^{1}$, Hasan Mukhibad ${ }^{1}$ \& Fatmala Dewi Aprilia ${ }^{1}$ \\ ${ }^{1}$ Faculty of Economics, Universitas Negeri Semarang, Central Java, Indonesia \\ Correspondence: Kardoyo, Faculty of Economics UNNES, Sekaran Campus, Gunungpati, Semarang, Central Java, \\ Indonesia. Tel: 62-8164-243-161.
}

Received: September 29, 2019

Accepted: October 25, 2019

Online Published: March 17, 2020

doi:10.5430/ijfr.v11n2p128

URL: https://doi.org/10.5430/ijfr.v11n2p128

\begin{abstract}
This study aims to examine the effect of knowledge, promotion, and religiosity on the interest in using Islamic banking services. The purpose of the next research is to examine the effect of knowledge on religiosity. In addition, this study also examines the effect of educational background and age on saving interest in Islamic banks. The population in this study are customers of Bank Syariah Mandiri, Brebes, Central Java, Indonesia. Ninety-nine research samples were obtained. The data collection method used was questionnaires. The data analysis method used was SEM-PLS. The results showed that only promotion proved to have a positive and significant effect on interest in using the services of Islamic banks. Knowledge and religiosity have not been proven to have a significant effect on interest in using services of Islamic banks. Likewise, background and gender do not have a significant effect. The next research result is that there is a positive and significant influence of knowledge on religiosity; there is also a positive and significant influence on the promotion of knowledge. This study recommends the importance of continuing socialization and education from Islamic banking stakeholders in Indonesia to continue introducing Islamic banks to the public.
\end{abstract}

Keywords: intention to use Islamic Banking services, knowledge, promotion, religiosity

\section{Introduction}

Islamic banking has been developing in Indonesia since 1992, alongside conventional banks that have existed so far. The presence of Islamic banking in Indonesia is considered capable of answering the difficulties that occur in conventional banking. The Indonesian Ulema Council (MUI) and the Indonesian Muslim Intellectual Association (ICMI) by involving the government and Muslim entrepreneurs established an Islamic bank in Indonesia in 1991. The existence of an Islamic bank in Indonesia was pioneered by Bank Muamalat Indonesia in 1992.

The Islamic banking industry has shown positive developments from year to year. BNI Syariah President Director, Abdullah Firman Wibowo said in the 2014-2018 period, Islamic banking was able to record a Compounded Annual Growth Rate (CAGR) of 15\%, higher than that of the national banking industry which recorded a CAGR of $10 \%$ (https://www.cnbcindonesia.com/syariah/20190608180708-29-77170/5-tahun-rerata-pertumbuhan-industri-perbanka n-syariah-15). Islamic banking statistics in Indonesia as of December 2018 (ojk.go.id) showed there are currently 14 Sharia Commercial Banks, 20 Sharia Business Units, and 167 Sharia People Financing Banks. The total assets of Islamic banking are around 466 billion rupiah which was less than $10 \%$ of the total banking assets in Indonesia.

However, the phenomenon shows that Islamic banking in Indonesia has not been an option for obtaining banking services. People still opt for conventional banking for savings and other services. Islamic banks are considered to be unable to provide better services than conventional banks. Another assumption is that Islamic banks are not different from conventional banks. Indonesia is a country with a majority Muslim population of $87.21 \%$ (www.bps.go.id). But the problem is that the number of Muslims with Islamic bank growth is not comparable. This is as stated by Suhartanto (2019) that Islamic banks are dynamic segments in the banking industry.

This study aims to examine the factors that influence people's interest in using Islamic banking services, especially in savings services. Damayanti (2017) stated that interest has a fairly close relationship with encouragement in an individual which then raises the desire to participate and be involved in something that interests him. Someone who 
is interested in an object will tend to feel happy when involved in the object so they tend to pay attention to the great attention to the object.

One of the factors that is able to influence someone in using the services of an Islamic banking is knowledge. Knowledge of Islamic banking will cause that person to understand Islamic banks, the benefits of saving at Islamic banks, and the difference with conventional banks. Murtadho (2013) and Nisak, Saryadi, \& Suryoko (2013) found that knowledge of Islamic banks has a positive and significant effect on saving interests in Islamic banks.

Interest in using the services of Islamic banks is also influenced by promotions conducted by Islamic banks. The more frequent and intensive promotion conducted by Islamic banks, the more people will be interested in using the services of Islamic banks. People will increasingly know about the services provided by Islamic banks. Many studies have proven that promotion can influence savings interest in Islamic banks positively and significantly (Arifin \& Khotimah, 2014; Ariyanti, 2015; Rahmanto, 2016).

Religiosity is also a determining factor in interest in using the services of Islamic banks. People who have a high level of religiosity will be increasingly interested in using the services of Islamic banks. The community will feel comfortable because they have carried out economic activities in accordance with religious teachings. Islamic banks apply Sharia principles in their operations. Many researchers have found a positive and significant effect of religiosity on saving interest in Islamic banks (Afiah, 2016; Andriani, 2015; Rahmanto, 2016; Shofwa, 2017). The results of the research by Bananuka, Kaawaase, Kasera, \& Nalukenge (2019) also show that religiosity is a significant determinant for the adoption of Islamic banking in non-Islamic developing countries (Uganda). Suhartanto (2019) found a significant effect of religiosity on intention toward Islamic banks.

This study will also examine the effect of educational background and gender on saving interest in Islamic banks. The higher the level of public education, the more likely it will be to choose Islamic banks. Amin, Abdul-Rahman, \& Razak (2014) found that education is an important instrument that is able to influence consumers in Islamic home financing preferences. Men will be more likely to be interested in saving at Islamic banks. As the family head, he will be able to make decisions. Kaakeh, Hassan, \& van Hemmen Almazor (2018) showed that men have a greater tendency to use Islamic banks. Haider, Changchun, Akram, \& Hussain (2018) stated that there are significant differences in intention to adopt Islamic mobile banking in Pakistan.

\section{Literature Review}

\subsection{Theory of Planned Behavior (TPB)}

TPB was conceived by Ajzen (1991) and is one of the models that can be used to assess someone's interest. This theory has been recognized as the best model for understanding behavior change and has been proven appropriate for assessing saving interests. Saving as a planned behavior is related to one's interests. According to the TPB, human actions are directed by three beliefs, namely behavioral, normative, and control beliefs (Azjen, 1991). Graphically, TPB is shown in Figure 1 below.

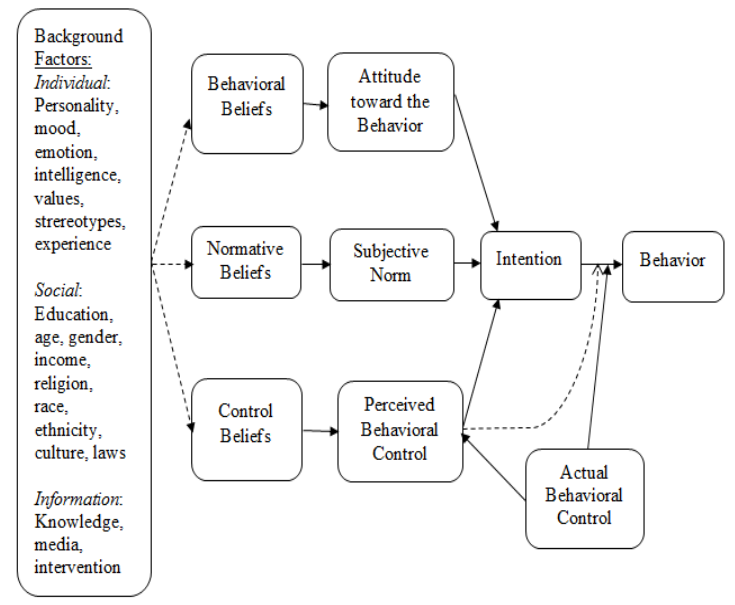

Figure 1. Theory of planned behavior

Sumber: http://people.umass.edu/aizen/tpb.background.html 


\subsection{Intention to Use Islamic Bank Service}

Aisyah (2013) stated that interest is a high affection towards a passion or desire. Interest is a person's tendency to determine the choice of activities. The influence of individual conditions can change one's interest. Therefore, it can be said that interest is unstable. Jogiyanto (2008) stated that interest (intention) is defined as the desire to conduct behavior. Behavioral intention is still an interest. Interest or intention is a desire to conduct behavior, but interest itself is not yet a behavior. Behavioral intention will determine its behavior. Bananuka et al. (2019) stated that intention is defined as how hard someone is willing to try to perform a behavior and what level of determination one is planning to use towards performing the behavior in question.

Intention to use Islamic Bank service can be interpreted as a desire from the public to use the services of Islamic banks, such as savings and other services. This desire is driven by information obtained about Islamic banks, both independently and from outside parties. Many factors affect interest. Aisyah (2013) mentions that culture, family, attitudes and beliefs, social motives, and motivation are determinants of one's saving interest.

\subsection{Research Hypotheses Development}

Knowledge is information that has been interpreted by someone using their history, experience, and interpretation scheme (Saraswati, 2016). Knowledge about Islamic banks is one of the factors that can influence the interest in using Islamic bank services. According to the theory of planned behavior, knowledge is one of the factors that can influence a person's behavior or actions. Knowledge about Islamic banks is also included in control beliefs. Control beliefs associated with the belief that behavior or work can be done. For example, with the knowledge and understanding of Islamic banks, it is hoped that it can generate public interest to do saving in Islamic banks.

Murtadho (2013) has found a positive and significant influence of knowledge on customers' interest to save at Islamic banks. A similar result was obtained by (Nisak et al., 2013). The results of the factor analysis show the significant influence of knowledge on the main preferences of saving on Islamic banking (Lestari, 2016). Other research results also showed that knowledge can increase customer interest in using Islamic banks (Chaouch, 2017).

Sales promotion, as a key element in marketing campaigns, is various sets of incentive tools, mostly short-term, designed to protect the image of a company or its individual products (Kotler \& Keller, 2008). Promotion is an attempt to notify or offer a product or service in order to attract potential customers. Promotion is also related to background, included in the information factor, namely the factors that will facilitate or hinder the performance of the behavior and the perceived strength of these factors. Various information, both through direct and indirect promotions will attract the attention of the public and increase public interest in using Islamic bank products, one of which is by saving at Islamic banks.

Ariyanti (2015) and Rahmanto (2016) found that promotion can affect the interest of saving in Islamic banks positively and significantly. Meanwhile, Arifin \& Khotimah (2014) failed to prove the effect of promotion on the decision of the community to choose an Islamic bank.

Religiosity is the form of religious aspects that have been adhered by individuals within their heart. The meaning of religiosity is described in several aspects that must be fulfilled to live the life properly to achieve happiness, both in this world and the hereafter (Shofwa, 2017). The level of religiosity is related to personality trait reflecting the level of religiosity a person has. The level of one's religiosity will affect the personality traits he possesses. The level of religiosity can affect one's interest in a job, especially if the work is related to worship. The higher the level of one's religiosity, the higher one's interest in saving at an Islamic bank regarding Islamic principles is.

Andriani (2015), Rahmanto (2016), and Afiah (2016) succeeded in proving the significant influence of religiosity on saving interest in Islamic banks. Shofwa (2017) and (Bananuka, Kasera, et al., 2019) (Bananuka, Kaawaase, et al., 2019) (Bananuka, Kasera, et al., 2019) also found the effect of religiosity on the decision of customers of savings products at Bank Syariah Mandiri. The results of the factor analysis show the significant influence of religiosity on the main preference for saving on Islamic banking (Lestari, 2016).

In addition to knowledge, promotion, and religiosity factors, there are other factors that will be tested in this study, namely educational background and gender. Educational background will influence the community in using the services of Islamic banks. The higher the level of education, the more likely it is to choose an Islamic bank. The public will increasingly understand about Islamic banks. Gender will also affect the intention to use Islamic banking services. This means that there are significant differences between men and women in using the services of Islamic banks. Men will tend to be more interested in Islamic banks than women will.

Based on the description above, the hypotheses developed in this study are as follows: 
H1 knowledge has a positive and significant effect on the intention to use Islamic banking services

$\mathrm{H} 2$ promotion has a positive and significant effect on the intention to use Islamic banking services

H3 religiosity has a positive and significant effect on the intention to use Islamic banking services

$\mathrm{H} 4$ educational background has a positive and significant effect on the intention to use Islamic banking services

H5 gender has a positive and significant effect on the intention to use Islamic banking services

H6 promotion has a positive and significant effect on knowledge about Islamic banks

H7 knowledge has a positive and significant effect on religiosity

\section{Method}

This is a quantitative research. The research design used in this study is a survey method. The survey method is used to obtain data from a particular natural place or original data to describe the state of the population. The population in this study was customers of Bank Syariah Mandiri, Brebes Sub-Branch Office. The number of customers is 8,750 people. The sampling technique in this study is the accidental sampling technique by selecting the sample using the Slovin formula. And obtained 99 respondents.

The dependent variable in this research is the intention to use Islamic banking services. The intention variable is measured by indicators developed from Ferdinand (2014), namely transactional interest, referential interest, preference interest, and explorative interest. The independent variables in this study were knowledge, promotion, religiosity, educational background, and gender. Knowledge of Islamic banks is measured by indicators, namely knowledge of Islamic banking, knowledge of the characteristics of Islamic bank products, and knowledge of satisfaction with services provided by Islamic banks.

Promotion is measured by indicators, namely advertising, sales promotion, publicity, and personal selling. Religiosity is measured by indicators; Beliefs or Ideologies, Religious or Ritualistic Practices, Experiences or Experiences, Religious or Intellectual Knowledge, and Consequences. Educational background is measured by the last level of Education and measured by dummy variables (undergraduate and non-graduate). Gender is measured by dummy variables, male and female.

Data collection techniques in this study were questionnaires technique. The types of questions used in the questionnaire in this study were closed questions. The questionnaires were developed from the opinions of experts and previous researchers. Data analysis methods used are descriptive statistical analysis and SEM-PLS analysis. The software used is WarpPLS version 6.0. Descriptive statistics used in this study are the determination of the average value (mean), maximum value, minimum value and standard deviation of each research variable. SEM-PLS analysis is used to test the research hypotheses that have been developed previously.

\section{Results and Discussion}

\subsection{Descriptive Statistics of Research Variables}

Table 1 shows the results of descriptive statistical analysis. The intention to use Islamic banking service variable is in the high category. This means that customer interest is very supportive to continue using the services of Islamic banks. Knowledge variables are included in both categories. Customers have a good understanding of Islamic banks. Promotion variable is in a good category, meaning that Islamic banks have carried out promotional activities well. Religiosity in a high category means that customers have a high level of religiosity and support the behavior of using the services of Islamic banks.

Table 1. Descriptive statistic of research variables

\begin{tabular}{llllll}
\hline No. & Research Variables & Min & Max & Mean & Std. Deviation \\
\hline 1. & Intention to Use Islamic Banking service & 15 & 40 & 31,89 & 4,783 \\
\hline 2. & Knowledge & 18 & 40 & 32,87 & 4,149 \\
\hline 3. & Promotion & 11 & 40 & 31,02 & 4,529 \\
\hline 4. & Religiosity & 39 & 55 & 49,96 & 3,862 \\
\hline
\end{tabular}




\subsection{Hypothesis Testing Results}

Table 2 shows the results of the Goodness of Fit Test. The results showed that it had fulfilled the required criteria. Therefore, the research model can be considered as fit and can be continued to the next stage of testing.

Table 2. Result of goodness of fit test

\begin{tabular}{|c|c|c|c|}
\hline Items & Criteria & Test Result & \\
\hline $\begin{array}{l}\text { Average path coefficient } \\
\text { (APC) }\end{array}$ & $\mathrm{P}<0.005$ & $\mathrm{APC}=0.194, \mathrm{P}=0.011$ & Meet the criteria \\
\hline Average R-squared (ARS) & $\mathrm{P}<0.005$ & $\mathrm{ARS}=0.355, \mathrm{P}<0.001$ & Meet the criteria \\
\hline $\begin{array}{l}\text { Average adjusted R-squared } \\
\text { (AARS) }\end{array}$ & $\mathrm{P}<0.005$ & $\begin{array}{l}\text { AARS }=0.334, \\
P<0.001\end{array}$ & Meet the criteria \\
\hline Average block VIF (AVIF) & $\begin{array}{l}\text { acceptable if } \quad<=5, \\
\text { ideally }<=3.3\end{array}$ & $\mathrm{AVIF}=1.344$ & Meet the criteria \\
\hline $\begin{array}{l}\text { Average full collinearity VIF } \\
\text { (AFVIF) }\end{array}$ & $\begin{array}{l}\text { acceptable if }<=5, \\
\text { ideally }<=3.3\end{array}$ & $\mathrm{AFVIF}=1.617$ & Meet the criteria \\
\hline
\end{tabular}

Figure 2 shows the results of testing the research hypothesis. Knowledge has a probability value $(\mathrm{P})$ of 0.11 with a coefficient $(\beta)$ of 0.12 to the intention to use Islamic banking services. This shows that knowledge has not been proven to have a positive and significant effect on the intention to use Islamic banking services. The same results were also obtained on the variables of religiosity, education, and gender which have probability values of more than 0.05 . This means that the variables of religiosity, education, and gender have not been proven to have a significant effect on the intention to use Islamic banking services.

The results also showed that the value of probability promotion of the intention to use Islamic banking services was less than 0.01 with a coefficient of 0.62 . This shows that promotion has a positive and significant effect on the intention to use Islamic banking services. The value of probability knowledge on religiosity is 0.03 or less than 0.05 with a coefficient of 0.18 . This means that knowledge has a positive and significant effect on religiosity. The probability value of promotion variable is less than 0.01 with a coefficient of 0.29 . This means that promotion has a positive and significant effect on knowledge.

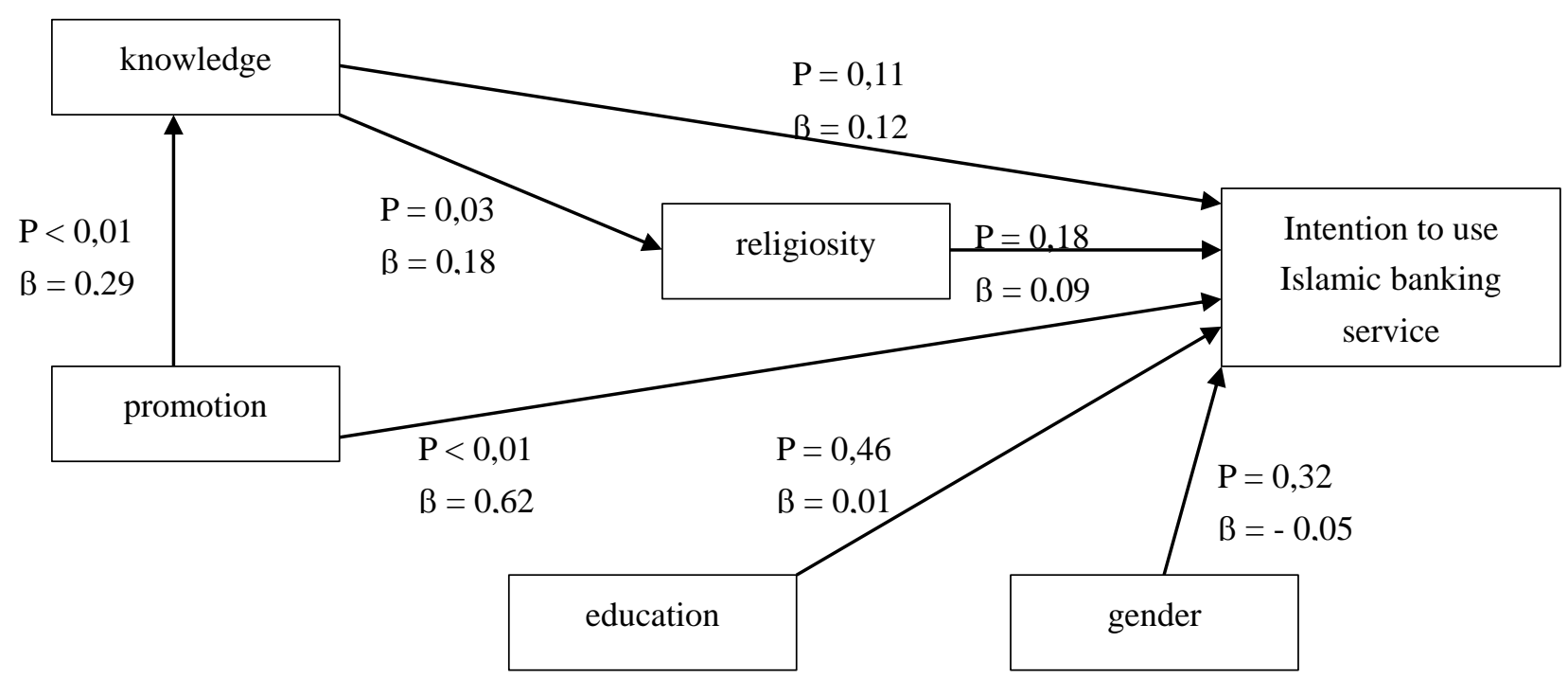

Figure 2. Results of hypotheses testing 


\subsection{Discussion}

Theory of planned behavior can be used to understand the intention to use Islamic banking services. TPB is also known as the social cognitive framework (Pitchay, Thaker, Azhar, Mydin, \& Thaker, 2019). This study uses the TPB framework to examine the effect of knowledge, promotion, and religiosity on the intention to use Islamic banking services. The results showed that only promotion proved to have a positive and significant effect. That is, customers of Islamic banks are not influenced by the level of knowledge and religiosity in determining the choice of using the services of Islamic banks. Customers are more influenced by the information conveyed by Islamic banks so that they will know more technically about the benefits of services provided by Islamic banks. This also shows that Islamic bank customers tend to be rational.

The results support the results of previous studies that showed a positive and significant influence of knowledge on intention (Chaouch, 2017; Murtadho, 2013; Nisak et al., 2013). Mbawuni \& Nimako (2017) found that knowledge is a determinant of bank customers' intention to adopt Islamic banking in Ghana. Meanwhile, Rahmanto (2016) found that promotion can affect savings interest in Islamic banks positively and significantly. While Arifin \& Khotimah (2014) and Ariyanti (2015) failed to prove the effect of promotion on the decision of the community to choose Islamic banks.

Religiosity has an impact on consumer attitudes toward Islamic banking in Egypt (Abou-Youssef, Kortam, Abou-Aish, \& El-Bassiouny, 2015). Religious motivation is an important factor influencing the intention to use Islamic banking (Kaakeh et al., 2018). Mbawuni \& Nimako (2017) also found the effect of perceived religion effect (PRE) on bank customers' intention to adopt Islamic banking in Ghana. Suhartanto (2019) found a significant direct effect between religiosity on behavioral intention toward Islamic banking.

However, there are researchers who found different results. Religious obligation was found to be a significant predictor Amin et al. (2014). The relationship between religious involvement (practice and interest) and attitude towards Islamic banks is found to be insignificant (Souiden \& Rani, 2015). Butt, Ahmad, Naveed, \& Ahmed (2018) found that religion is not a major factor capable of influencing new users of Islamic banks services, but is more likely to be influenced by service quality, comfort, branch office networks, and others.

The results also showed that education and gender were not proven to have a positive and significant effect on the intention to use Islamic banking services. The results of this study are in accordance with the results of previous studies. Shome, Jabeen, \& Rajaguru (2018) failed to prove the significant effect of education and gender on consumers' decision to choose the services of Islamic banks at the United Arab Emirates. Kaakeh et al. (2018) also showed that the potential of Islamic banking customers in Spain are Muslim (Spanish, Moroccan or Pakistani), male, and did not reach university degrees in their education. There is a negative influence from respondents who have a higher education background (master and doctoral). However, the results of this research did not support the results of the research by Amin et al. (2014) who found that education is an important instrument that is able to influence consumers in Islamic home financing preference.

Kaakeh et al. (2018) showed that men have a greater tendency to use Islamic banks services. Haider et al. (2018) stated that there are significant differences in intention to adopt Islamic mobile banking in Pakistan. Men are more likely to use Islamic mobile banking. Amin et al. (2014) showed that gender and academic qualification has little effect on the acceptance of Islamic home financing.

The results also showed that promotion has a positive and significant effect on knowledge about Islamic banks and knowledge has a positive and significant effect on religiosity. This means that the information conveyed by Islamic banks, even though they are promotional in nature, is able to increase customers' knowledge about Islamic banks. The better and more complete the information delivered, the better the customer's knowledge, which will ultimately increase the level of customer religiosity.

\section{Conclusion}

The results show that only promotion proved to have a positive and significant effect on the intention to use Islamic banking services, while other variables (knowledge, religiosity, education, and gender) have no significant effect. Thus, promotion is the only factor that greatly influences Bank Syariah Mandiri customers to use the services provided. The results also show that knowledge has a positive and significant effect on religiosity, and promotion has a positive and significant effect on knowledge. That is, the better the knowledge of Islamic banks, the higher the level of customer religiosity. Likewise, promotions carried out by Islamic banks will increase customer knowledge about Islamic banks. 
Suggestion from this research is promotion must be maintained by Islamic banks because it is proven to greatly affect customers. In addition, Islamic banks together with other stakeholders can carry out socialization and education activities to the public in order to further increase public interest in using the services of Islamic banks. Today's society is increasingly rational. The more Islamic banks do not care, the more indifferent to Islamic banks the public become. Islamic banks should carry out more attractive promotional activities such as gift-giving and others.

\section{References}

Abou-Youssef, M. M. H., Kortam, W., Abou-Aish, E., \& El-Bassiouny, N. (2015). Effects of religiosity on consumer attitudes toward Islamic banking in Egypt. Marketing Intelligence and Planning, 33(6), 786-807. https://doi.org/10.1108/IJBM-02-2015-0024

Afiah, Y. (2016). Pengaruh Religiusitas dan Persepsi Masyarakat Desa Bode Lor Terhadap Minat Menabung di Perbankan Syariah. IAIN Syekh Nurjati Cirebon.

Aisyah. (2013). Pengaruh kualitas pelayanan terhadap minat nasabah untuk menabung (Study kasus pada PT. Bank Mega Syari'ah Cabang Semarang). IAIN Walisongo Semarang.

Amin, H., Abdul-Rahman, A. R., \& Abdul-Razak, D. (2013). An integrative approach for understanding Islamic home financing adoption in Malaysia. International Journal of Bank Marketing, 31(7), 544-573. https://doi.org/10.1108/IJBM-02-2013-0008

Amin, H., Abdul-Rahman, A. R., \& Razak, D. A. (2014). Theory of Islamic consumer behaviour: An empirical study of consumer behaviour of Islamic mortgage in Malaysia. Journal of Islamic Marketing, 5(2), 273-301. https://doi.org/10.1108/JIMA-06-2013-0042

Andriani, A. (2015). Pengaruh persepsi dan religiusitas santri terhadap minat menabung di Perbankan Syariah (Studi kasus di Pondok Pesantren Al-Falah Mojo Kediri). IAIN Tulungagung.

Arifin, A., \& Khotimah, H. (2014). Akuntansi dan perbankan syariah 1 163. In Seminar Nasional dan Call for Paper Program Studi Akuntansi FEB UMS (pp. 163-184). Surakarta: Prodi Akuntansi FEB UMS.

Ariyanti, W. D. (2015). Pengaruh Kualitas Layanan, Kepercayaan, Promosi terhadap Minat Menabung Nasabah pada Bank CIMB Niaga Syariah di Surabaya. Sekolah Tinggil Ilmu Ekonomi Perbanas Surabaya.

Azjen, I. (1991). The Theory of Planned Behavior. Organizational Behavior and Human Decision Processes, 50, 179-211.

Bananuka, J., Kaawaase, T. K., Kasera, M., \& Nalukenge, I. (2019). Determinants of the intention to adopt Islamic banking in a non-Islamic developing country: The case of Uganda. ISRA International Journal of Islamic Finance. https://doi.org/10.1108/JJIF-04-2018-0040

Bananuka, J., Kasera, M., Muganga, G. N., Musimenta, D., Ssekiziyivu, B., \& Kimuli, S. N. L. (2019). Attitude: mediator of subjective norm, religiosity and intention to adopt Islamic banking. Journal of Islamic Marketing. https://doi.org/10.1108/JIMA-02-2018-0025

Butt, I., Ahmad, N., Naveed, A., \& Ahmed, Z. (2018). Determinants of low adoption of Islamic banking in Pakistan. Journal of Islamic Marketing, 9(3), 655-672. https://doi.org/10.1108/JIMA-01-2017-0002

Chaouch, N. (2017). An Exploratory Study of Tunisian Customers' Awareness and Perception of Islamic Banks. International Journal of Islamic Economics and Finance Studies, 3(2), 7-32. https://doi.org/10.25272/j.2149-8407.2017.3.2.01

Damayanti, S. (2017). Pengaruh Pandangan Islam, Pelayanan Dan Keamanan Terhadap Minat Nasabah Untuk Menabung Di Bank Syariah Mandiri Cabang X. Jurnal Manajemen Dan Pemasaran Jasa, 9(1), 17-34. https://doi.org/10.25105/jmpj.v9i1.1412

Ferdinand, A. T. (2014). Metode Penelitian Manajemen: Pedoman Penulisan Skripsi. Tesis, dan Disertasi Ilmu Manajemen. Semarang: BP UNDIP.

Haider, M. J., Changchun, G., Akram, T., \& Hussain, S. T. (2018). Does gender differences play any role in intention to adopt Islamic mobile banking in Pakistan? An empirical study. Journal of Islamic Marketing, 9(2), 439-460. https://doi.org/10.1108/JIMA-11-2016-0082

Jogiyanto. (2008). Sistem Informasi Keperilakuan. Yogyakarta: ANDI Offset.

Kaakeh, A., Hassan, M. K., \& van Hemmen Almazor, S. F. (2018). Attitude of Muslim minority in Spain towards 
Islamic finance. International Journal of Islamic and Middle Eastern Finance and Management, 11(2), 213-230. https://doi.org/10.1108/IMEFM-11-2017-0306

Kotler, P., \& Keller, K. L. (2008). Manajemen Pemasaran (Edisi ketiga belas). Jakarta: Erlangga.

Lestari, A. M. (2016). Pengaruh Religiusitas, Produk Bank, Kepercayaan, Pengetahuan, dan Pelayanan Terhadap Preferensi Menabung pada Perbankan Syariah (Studi Kasus Pada Mahasiswa Fakultas Ekonomi Dan Bisnis Universitas Brawijaya Malang). Jurnal Ilmiah Mahasiswa FEB UB, 3(1).

Mbawuni, J., \& Nimako, S. G. (2017). Determinants of Islamic banking adoption in Ghana. International Journal of Islamic and Middle Eastern Finance and Management, 10(2), 264-288. https://doi.org/10.1108/IMEFM-04-2016-0056

Murtadho, M. I. (2013). Pengaruh pengetahuan tentang bank syariah terhadap minat nasabah untuk menabung di Bank Negara Indonesia Syariah Cabang Semarang. Fakultas Syari'ah dan Ekonomi Islam. IAIN Walisongo.

Nisak, A., Saryadi, \& Suryoko, S. (2013). Pengaruh Kelompok Acuan dan Pengetahuan Tentang Perbankan Syari'ah Terhadap Minat Menabung di Perbankan Syari'ah Semarang. Jurnal Ilmu Administrasi Bisnis, 2(1), 44-50. Retrieved from https://ejournal3.undip.ac.id/index.php/jiab/article/download/1619/1613

Pitchay, A. B. A., Thaker, M. A. B. M. T., Azhar, Z., Mydin, A. A., \& Thaker, H. B. M. T. (2019). Factors persuade individuals' behavioral intention to opt for Islamic bank services: Malaysian depositors' perspective. Journal of Islamic Marketing. https://doi.org/10.1108/JIMA-02-2018-0029

Rahmanto, K. (2016). Pengaruh Tingkat Religiusitas, Kualitas Pelayanan, dan Promosi Terhadap Minat Masyarakat Desa Sraten Kab. Semarang Untuk Menabung di Bank Syariah. Skripsi. IAIN Salatiga.

Saraswati, N. (2016). Pengaruh pengetahuan masyarakat terhadap minat menjadi nasabah Bank Muamalat KCP Magelang (studi kasus pada masyarakat Kota Magelang). Tugas Akhir. UIN Walisongo Semarang.

Shofwa, Y. (2017). Pengaruh Kualitas Produk Dan Religiusitas Terhadap Keputusan Nasabah Produk Simpanan Pada Bsm Cabang Purwokerto. El-Jizya: Jurnal Ekonomi Islam, 4(1), 189-215. https://doi.org/10.24090/ej.v4i1.2016.pp189-215

Shome, A., Jabeen, F., \& Rajaguru, R. (2018). What drives consumer choice of Islamic banking services in the United Arab Emirates?. International Journal of Islamic and Middle Eastern Finance and Management, 11(1), 79-95. https://doi.org/10.1108/IMEFM-03-2017-0066

Souiden, N., \& Rani, M. (2015). Consumer attitudes and purchase intentions toward Islamic banks: The influence of religiosity. International Journal of Bank Marketing, 33(2), 143-161. https://doi.org/10.1108/IJBM-10-2013-0115

Suhartanto, D. (2019). Predicting behavioural intention toward Islamic bank: a multi-group analysis approach. Journal of Islamic Marketing. https://doi.org/10.1108/JIMA-02-2018-0041 